\title{
Rethinking academic tasks as a way to fight against cyber-plagiarism in higher education
}

\section{El rediseño de las tareas académicas como forma de combatir el ciberplagio en la universidad}

\author{
Isabel Tello Fons ${ }^{1}$ \\ Cinta Gallent Torres ${ }^{2}$ \\ Universidad de Valencia, España
}

Universidad Politécnica de Cartagena, España

\section{ABSTRACT}

The phenomenon of cyber-plagiarism has already been described by many authors (Cavanillas, 2008; Comas et al., 2011; Jones, 2009; Rowe, 2004; Underwood and Szabo, 2003), who have pointed out both the reasons that cause it and the measures to reduce this practice taking into account different points of view -institutional, academic and ethical measures, among others. This work aims to draw attention to the responsibility that could 1 isabel.tello@cud.upct.es Centro Universitario de la Defensa - Universidad Politécnica de Cartagena, Cartagena, España. https://orcid.org/0000-0001-7533-1064 https://scholar.google.es/citations? hl=en\&user $=8 b T p 5 B o A A A A J$ https://www.researchgate.net/profile/lsabel Tello2/research $2 \quad$ Cinta Gallent Torres2 cinta.gallent@uv.es

be ascribed to faculty when talking about cyber-plagiarism at online university studies. Instructors have in their hands the possibility of counteracting academic dishonesty by improving the tasks they give to students as deterrence to fraud and malpractice. To this end, we suggest some ideas to rethink tasks and assignments to make them more motivating and engaging to students. These recommendations stress creativity, personal reflection, and the use of any kind of (educational) technologies as measures to fight cyber-plagiarism at online university studies.

KEYWORDS: cyber-plagiarism, academic dishonesty, tasks, educational strategies, e-learning, higher education. 


\section{RESUMEN}

El fenómeno del ciberplagio ya ha sido descrito por multitud de autores (Cavanillas, 2008; Comas et al., 2011; Jones, 2009; Rowe, 2004; Underwood and Szabo, 2003) que han señalado tanto las razones que lo provocan como las medidas para reducirlo teniendo en cuenta el punto de vista académico, ético, o el de las instituciones universitarias, entre otros. Este estudio pretende reflexionar sobre la responsabilidad que tenemos los profesores en cuanto al ciberplagio si tenemos en cuenta las tareas que asignamos a nuestros alumnos. $\mathrm{Si}$ dichas tareas son motivadoras, inspiradoras, claras y diferentes, los estudiantes se verán menos tentados a hacer trampas. Este estudio se encuadra en el marco de la educación online $y$ en él se hace un repaso de las directrices generales que los profesores debemos tener en cuenta al diseñar tareas. Se propondrán algunas ideas para rediseñarlas con el fin de alejar a los estudiantes de la deshonestidad académica.

PALABRAS CLAVE: ciberplagio, deshonestidad académica, tareas, estrategias educativas, e-learning, educación superior.

\section{INTRODUCTION}

Academic cyber-plagiarism, also called academic dishonesty, is a concept that encompasses fraud, electronic tools and education. In Jones's words, cyber-plagiarism refers to "cutting and pasting material from the Internet instead of writing in one's own words", which becomes "a new twist on the age-old problem" (2009, p. 17). Plagiarism has always existed, but cyber-plagiarism is a practice that has grown during the past years at a fast pace due to the unlimited access to information on the Internet. As Underwood and Szabo point out, "the Internet has changed the dynamics of dishonest academic practice; access is no longer for the knowing few but is there for the majority" (2003, p. 469). Cyber-plagiarism, thus, not only refers to the appropriation of digital written texts, but to any material such as videos, audios, images, datasets, spreadsheets, PowerPoint slides, computer codes, etc.

Students are asked to do tasks, projects, and assignments by using the Internet, and sometimes the line between a legal or an illicit behavior is not always clear. In fact, crossing the line and copying information without citing the original source is very simple. Hence, it is not only essential to teach citation techniques and strategies to paraphrase and incorporate quotations correctly, but to commission students with tasks and assignments which will discourage cyber-plagiarism. This leads us to reflect on (i) the type of tasks instructors design, (ii) the need to set and plan more meaningful tasks and (iii) how these tasks can prevent resorting to dishonest actions when using the Internet.

Certainly, the development of ICTs forces higher education institutions to control the use of digital resources (particularly in academic tasks and exams) and encourage the university community to use these resources with integrity, which must be one of the most important values in education. Needless to say that if students leave the university with a diploma, they have to earn it without basing their success on other people's work.

The studies on academic cyber-plagiarism have considerably increased in the past years, which reflects the interest on the subject (Comas et al., 2011; Gómez-Espinosa et al., 2016; Moten et al., 2013; Olivia-Dumitrina et al., 2019; Ruiz Bejarano, 2016; Sarriá and De Francisco, 2018). In such studies, surveys are normally the tools used to measure the extent and the circumstances under which students are prone to cyber-plagiarism. Results are often similar, as they show how students are aware of the most popular forms of cyber-plagiarism, but they still plagiarize, intentionally or unintentionally, for a number of reasons, which often include lack of 
time, sense of impunity, fear of failure, among others.

\section{E-LEARNING AND CYBER-PLAGIARISM}

Online learning is often associated with a more autonomous and depersonalized education, a fact which is supposed to favor cyber-plagiarism (Dickey, 2004; Harris, 2012; Howard, 2007; Pardo Iranzo, 2014; Pavlakis and Kaitelidou, 2012; Underwood and Szabo, 2003). That is to say that e-learning, more than any other kind of education, may entail an absence of responsibility regarding cyber-plagiarism that would be justified by the very nature of distance education. This idea is also connected to others such as teachers' permissiveness when grading tests and assignments and students' alleged impunity when submitting plagiarized tasks. Some studies, such as Nuere (2002) also suggest that the results of evaluation processes tend to be less reliable in distance education than in face-to-face education, although this author admits that in the submission of assignments the situation is similar regardless the kind of education.

Students' poor concept of plagiarism, scarce academic and reference skills, laziness, lack of motivation, little follow-up by teachers, inadequate tasks, feeling that the commissioned assignments are a waste of time, (self)demand for high grades and/or fear of failure, inadequate admission criteria, and the need to defy the system are the most repeated factors that would encourage students to plagiarize in a face-toface teaching context (Cebrián-Robles et al., 2018; Darwish and Sadeqi, 2016; Dawson, 2004; Devlin and Gray, 2007; Dordoy, 2002; Mahabeer and Pirtheepal, 2019; Park, 2003; Reducindo et al., 2017; Ronda-Pérez et al., 2015; Sentleng and King, 2012). Some factors that would encourage cyber-plagiarism, especially when talking about e-learning education, may be added to these, as the students' sense of distance from their instructors and the belief that the information on the Internet does not belong to anybody and can be used in any way.

\section{MOTIVATION AS A TOOL AGAINST CYBER- PLAGIARISM}

Academic tasks using technology and being related to the real world are proven to increase students' involvement in the contents explained (Angelo and Cross, 1993; Forte and Bruckman, 2006; Holley and Boyle, 2012; Fernández et al., 2017; Salgaonkar and Divate, 2017). Some software programs, as a matter of fact, have become common tools for instructors to carry out motivating tasks in class. Tasks using $\mathrm{Hot}$ Potatoes, Kahoot!, Padlet, WebQuest, Edublog, etc., allow students to learn in an amusing way, encourage participation and catch students' attention until the end of lessons (Iwamoto et al., 2017).

In addition, if tasks have to do with students' recreational interests or career goals (Hass and Osborn, 2007; Tibbetts et al., 2015), they will be encouraged in doing them from a more critical and personal point of view. "By changing the perception of the activity (i.e., helping students perceive tasks as personally important), it may be possible to influence interest" (Tibbetts et al., 2015 , p. 37). Therefore, it may be assumed that originality, creativity and motivation are positive factors in task design that may lead to dissuade students from turning to cyber-plagiarism.

The impact that assigned tasks have on (cyber) plagiarism rates has already been tackled by some authors (Al Darwish and Sadeqi, 2016; Christensen, 2011; Davids and Waghid, 2017; Fraser, 2013; Jiménez Torres, 2018). They usually point at measures and ideas to counteract this problem through the kind of assignments and assessment activities. Some studies support close monitoring of students' work. For example, Sabieh (2002) implemented a five-step plan to have students actively involved: providing interesting topics, offering clear guidelines, 
helping with technology and with research steps, and making students aware of plagiarism. Likewise, Fraser (2013) suggested specific ideas such as using tutorial sessions wisely or reinforcing the intended learning outcomes of students' assigned work.

However, most studies stressed the importance of designing motivating tasks and assignments. Born (2003) or Al Darwish and Sadeqi (2016) highlighted the importance of giving students unique and unusual writing assignments to overcome plagiarism. Nuere (2002) suggested activities to promote spontaneity, creativity, and students' own ideas. In Johnson's words "educators would be better spent creating assignments that require original, thoughtful research" (2004, p. 549). In line with this, Howard (2002) analyzed teachers' role in plagiarism and suggested that instructors' pedagogy has not probably adjusted to contemporary circumstances as readily as have our students, which would explain giving the same paper assignment semester after semester to a lecture class of one hundred students. Also GómezEspinosa et al. (2016) carried out a study by which an assignment was redesigned in a more engaging way, and this new approach led to a decrease in cyber-plagiarism, thus concluding that tasks which promote involvement, originality and creativity have a lower cyber-plagiarism rate. According to Christensen (2011), tasks should ideally address, in the first place, students' critical thinking instead of problems already prepared; and secondly, writing with their own words instead of allowing them to copy information from a written source or offering them all the data. Jiménez Torres (2018) suggested that "universities could take certain measures such as reducing the groups of students for each teacher so that they can spend more time assessing the originality of the work" (para. 9). Focusing on assessment activities, Olt (2002) and Davids and Waghid (2017) recommended they should be embedded in the learning experience, avoiding standardized, long assessment activities and implementing purposefulness.

As shown in this brief review, studies dealing with the role of faculty and tasks agree on the idea that designing more motivating work can be a weapon against plagiarism.

\section{ARE THERE ANY EFFORTS BEING DEVOTED TO TASK DESIGN AT AN INSTITUTIONAL LEVEL?}

Universities that openly deal with (cyber) plagiarism through initiatives and campaigns usually provide resources and information to educate students. There is a good number of universities implementing good practices around Europe, Ibero-America and the USA. That is the case of the University of Oxford, Université du Québec à Montreal, The Ohio University, Universitat de les Illes Balears, Universidad de Extremadura, Universidad de Sevilla, Universidad del Claustro de Sor Juana, among many others. They all provide many resources - online surveys, audio visual materials, links to articles and legislation, plagiarism protocols in case of doubt, institutional committees for discipline, etc. - offering students clear and practical information on the subject. Fewer institutions, however, address these initiatives to instructors and/or tackle the kind of assignments and their design as a measure to prevent (cyber) plagiarism. Most institutions' only guidance or resources for the faculty are limited to computer tools to identify fraud.

Efforts addressing the design of tasks and assignments are still timid. Universidad del Claustro de Sor Juana, in Mexico, published a handbook to detect, prevent and respond to plagiarism (Moreno Jiménez and Carrillo Martín, 2019). The website of the University of Maryland (https://www.studentconduct.umd.edu/) features an Office of Student Conduct, where a Code of Academic Integrity can be found. It is a reference 
document related to dishonest actions. Its Student Honor Council involves many members of the staff and about forty student leaders. There is also the Integrity, Character and Ethics (ICE) Award, which may be acknowledged to students, faculty and staff. Besides, many resources are available for students, parents and faculty. Among those aimed at faculty, there is a rubric to check how well instructors are promoting academic integrity in class, a sample syllabus text for professors to put in their syllabi, reports and surveys on academic integrity at the university, or tips on how to prepare for an honor hearing, among others. Regarding teaching methodology, this is only briefly referred in the Q\&A about the Code of Academic Integrity. To the question "What can faculty members do to reduce academic dishonesty?", the university states that "creative pedagogy also can discourage academic dishonesty. Plagiarism, for example, may be reduced if students are asked to discuss their papers in class and respond to questions from other students and the instructor".

The Universidad de Granada, in Spain, with its Proyecto de Innovación y Buenas Prácticas Docentes, a project for innovation and good teaching practices in the Humanities, takes into account the instructors' role. The project was created in 2011 to provide technological and scientific tools to foster respect for intellectual property. The sixth objective of the project mentions the importance of "motivating students in their academic tasks so that they understand that their own effort is much more satisfying than copying other people's texts" (Heine \& Martín García, 2013, p. 1172). To achieve this objective, the university offered a seminar by a visiting expert.

Undoubtedly, the scarce examples found underscore the need for educational institutions to educate the whole university community, giving them the tools they need to prevent, raise awareness and redress cyber-plagiarism.

\section{WHY SHOULD WE RETHINK TASKS?}

Assignments, tasks, projects and exams are the means by which faculty assess understanding and knowledge acquisition, so rethinking and redesigning them on a regular basis becomes necessary to prevent students from getting involved in dishonest behavior.

Comas et al. (2011) already suggested this when summarizing the most important academic dishonest actions in three axes: (i) cases of fraud in the exams, (ii) actions related to the preparation and presentation of assignments, and (iii) actions that occur as a consequence of the relationship among students. The second of these axes is directly associated to the teaching functions and to the tasks and assignments that students are asked to submit. The degree of responsibility that faculty has towards cyber-plagiarism when designing tasks and assignments is something no one can ignore. Moreover, redesigning tasks to avoid academic dishonesty may be the measure against cyber-plagiarism with the most didactic approach. Unlike measures such as grade penalties, course failing, disciplinary actions or suspension/expulsion, task redesign avoids students' penalization to focus on pedagogical solutions (Barberá, 2016).

The following guidelines for mitigating cyberplagiarism through the redesign of tasks are thought for e-learning higher education, a learning experience increasingly booming because of the attractiveness of its nature, particularly for adult learners. Reassessing tasks and assignments may particularly be useful in an online teaching and learning environment, where students may be discouraged by factors such as the lack of direct contact with instructors or the feeling of not living a regular college experience. Traditional tasks reinforce the belief that online university studies provide a large amount of theoretical content and that students are requested tasks and assignments that are both monotonous, boring and similar to each other. 
Nevertheless, e-learning instructors are not alien to the heavy teaching load most faculty complain about (Howard, 2002; Mahabeer and Pirtheepal, 2019), and possibly due to this the assignments given to students often lack originality and critical content.

It should be noted that the higher education system favors academic writing at the expense of personalized and spontaneous writing, a fact which students are not always familiarized with. Reconsidering activities to encourage creativity and personal reflection, in addition to keeping students away from plagiarism, will make them more valuable to a rapidly changing world, a future professional milieu in which they will make use of what they have learnt during their university studies. According to Taddei (2009), companies need the most creative individuals, those who are able to take the initiative, and nations want to have a workforce capable of creating value and jobs, while meeting the challenges of the moment at the same time.

\section{RECOMMENDATIONS TO TASK DESIGN}

Rethinking tasks and assignments involves exploring an unknownterrain that some instructors may take with reluctance. Increasingly, however, innovative tools or new methodologies are being adopted to make lessons more engaging and dynamic. Considering that inspiring assignments may deter students from plagiarizing, they should include relevant, meaningful, and motivating ideas and examples. They should encourage some personal reflection as well, for example prompted by questions that allow students give their opinion, solve a practical case or, better yet, set it out.

The following are a handful of aspects that may help instructors plan tasks and assignments in a more engaging way. To begin with, preparatory tasks such as task scaffolding, annotated bibliographies, and storyboarding are proved to be very useful in combating cyber-plagiarism
(Casey et al., 2014; Hale, 2018; Harris, 2012; Stabingis et al., 2014; Talab, 2004; Thompsett and Ahluwalia, 2010). Therefore, doing this kind of exercises before giving an assignment may encourage students to explain their own arguments while developing critical thinking.

Receiving clear instructions is key in any learning process. Frequently, the task instructions are the same year after year. The particularities of some subjects make difficult to modify the tasks from one academic year to the next one. In that case, it is advisable to change their approach to discourage students from resorting to copy and paste. Faculty must provide clear and precise guidelines and avoid ambiguity. It is important to show students where to find the information that may support their work. The use of the Internet as the only source of documentation should be questioned and even sanctioned if we want to encourage the creation of personal texts.

Time is another important factor, and it must be seen in two ways. On the one hand, time given to finish tasks should be shortened if we want to fight discouragement and laziness, but especially to minimize using copy and paste. On the other hand, due to their economic and personal circumstances, adult students may particularly face a time limit to complete their programs. Regarding this last case, Raes considers that not having enough time is one of the reasons plagiarists would copy, often triggered by the amount of work requested in each subject. Consequently, cyber-plagiarism would be "a very necessary evil" (2009, p. 96) for those who do not have time to invest in their assignments, which causes, at the same time, a step back in the meaning of academic responsibility.

Rubrics are versatile tools. They not only assess learning outcomes, they are helpful in guiding students' performance (Lehmand, 2010; Razi, 2015). They avoid ambiguity as well, since students have less chances for straying on other aspects than those in the rubric. Regarding 
homework, we should make sure that it is directly related or quite similar to the examples already explained, as one of the reasons for cyberplagiarism is students' lack of confidence in their own work. If homework is more affordable, students' confidence in their ability to perform tasks successfully will increase.

Group work stands as an important tool. Tasks that require a greater degree of collaboration will help deter students from cyber-plagiarism. For such work to be coherent, it must be planned properly, and participation of the group members should be active. The roles in the group must be equitably distributed (in case of cyber-plagiarism, all members will be responsible). Assignments could include a diary where the preparation of each part of the task in relation to the rest of the work is described. Students will adopt an active role by completing it and sharing their ideas critically.

Flipped classroom can fulfil a dissuasive function as well. The inverted class, according to Fernández et al., 2017, is "a teaching approach in which traditional class and self-learning activities are reversed or 'overturned'” (p. 1119). Among the advantages of this methodology, there's "a change in the responsibility to learn about students" (p. 1120). Flipped learning uses videos through which students acquire prior knowledge that will be shared afterwards with the rest of the class. Instructors, at that moment, check and consolidate learning. Integrating videos within tasks might be a measure against cyber-plagiarism if we think about the greater difficulty for students to copy the content from videos. They may want to use some information from them, so they will need to be previously taught to paraphrase. Students could be asked, for instance, to collect information from the video that will later be the topic for discussion. This information may be presented in different formats. Students will need to explain where the information comes from, as well as the appropriateness of their choice, following instructors' guidelines. Nevertheless, it must be said that even if it is harder for students to plagiarize videos, those who have good skills with computers and software programs are more and more able to access that information easily.

As regards the citation sources, even if students believe they know how to reference their sources, studies show that they don't do it appropriately (Comas et al., 2011; Devlin and Gray, 2007; Park, 2003; Talab, 2004). In this sense, the question posed by Simonnot (2014, p. 227-228) is very relevant: "How to integrate this practice [the citation] when we have not been made sufficiently aware, in school, about the explicit role played by citations and we have not been exposed to them?" Tasks in which students are entrusted with plagiarized assignments and which are based on the finding and correction of the citation may be a way to increase awareness on the importance of citing sources. Moreover, creating activities that tackle this competence playfully will be good to cite sources correctly. Web-based tools such as Kahoot! or Socrative are easy to use and allow students to create their own quizzes, which can be more motivating. In a later phase, students could act as teachers making the rest of the students take the quizzes they have created. In addition to this, instructors can always resort to Mendeley, Zotero, EndNotes, among other reference management software programs, to show students the tools commonly used in academia.

In general, any use of technology is beneficial as long as clear instructions to do the task are provided and the use of electronic tools is feasible. E-learning implies the use of technology, which is usually appealing for students, but all activities involving a use of ICT tools may be a good way to prevent cyberplagiarism. These activities not only get students out of monotonous traditional tasks, but they encourage them to be focused on the correct 
use of a new tool. Besides game-based, learning software programs already mentioned, students may engage in the creation of blogs, infographics, collaborative online glossaries, electronic mind maps or video recordings with tools such as Blogger, Picktochart, EdPuzzle, PlayPosit, Youtube and MindUp, to name a few. Holley and Boyle (2012) are some of the authors that highlight Open Educational Resources (OERs) as a bank of accessible multimedia materials for teachers that allow them to develop motivating tasks. This work also suggested that students themselves design the tasks through online task generators such as GLO Maker. That would make them show their ability to link activities with learning outcomes. Likewise, social media, as an important part in students' everyday lives, should be a motivating tool as well. Used as homework, making students write on Twitter or post on Instagram for didactic purposes, may provide personal and original contributions.

Inevitably, rethinking tasks to counteract cyberplagiarism leads us to consider tools designed to identify academic fraud in assignments and exams. All academic institutions are equipped with anti-plagiarism software, but when it comes to cheating, students know very well how to avoid it without being caught. Some can manipulate a text in a matter of seconds and pretend to be an original one in such a way that software cannot identify. This is surprising if we consider that the time spent in cheating could be invested in creating an original text. It is obvious that anti-plagiarism tools are not a panacea: their reliability level is still insufficient and so it is the faculty's commitment to use them appropriately.

Bergardàa (2009) considers that purchasing plagiarism detection software to fight against cyber-plagiarism is an absurd excuse that educational institutions should forget. However, the use of these tools to prepare students' submission of tasks is supported by many others. These studies proved that anti-plagiarism software can promote academic honesty (Batane, 2010; Chew et al., 2013; Heckler, 2013; Ledwith and Rísquez, 2008) as long as it is used with a didactic aim. The anti-plagiarism software can be explained to students, who will use it with their own work. They will analyze the results and present a brief report commenting on them. This will help students to take their personal creations more seriously, respect others' intellectual property and reflect on the critical and responsible use of information.

Linked to the above, if we rely on Biagioli's idea (2012, cited in Bessy and Chateauraynaud, 2015), who asks whether plagiarism can become a different form of learning, another turn of the screw to the task design might be suggested. Biagioli defends the idea that "good plagiarism does not question the content and scientific veracity. Although it hides the author's identity and harms his credit, the veracity of the plagiarized text can be even better, especially when it has been subject of several evaluations" (p. 198). Some questions arise from his reflection: would it be possible to find a didactic use in cheating and plagiarism? Could the process of copying, editing, or re-reading these collages become a meaningful learning experience for students? Some authors point directly to the feasibility of making students work with texts copied from the internet (Jones, 2009; Lessig, 2004). They focus on the use of copy and paste in a creative and rewarding way, for example, by making students compare different fragments of copied texts and draw a critical opinion.

All in all, faculty's attitude towards change will make the difference. The more willing to rethink and reshape tasks, the more motivated students will be as well. Undoubtedly, this will help students to carry out the assignments in a different spirit. 


\section{CONCLUSION}

The above ideas will lead us to reflect on how tasks, assignments and exams could be more challenging and meaningful for our students. Nevertheless, they need to be developed to adapt to the specific competences and learning outcomes of each course. Implementing these ideas will allow instructors to find out whether reassessing and redesigning tasks makes our students less prone to cyber-plagiarize. In a future work, these results will be compared to those obtained from the accomplishment of tasks and assignments with the traditional approach.

Reflecting on the tasks and assignments we give our students can only be worthwhile if there is a real awareness of its usefulness and a critical and responsible determination. Instructors must communicate what they want to achieve with the tasks and what they want to avoid as the only way to make students assimilate their share of responsibility. If we want our tasks to encourage reflection and personal contribution, we must show our students that we also devoted time and reflection to the design of those tasks.

The nature of distance learning frequently encourages cheating more than face-to-face education, but we cannot stop the advance of technological means that make education increasingly global and within the reach of more people. Underwood and Szabo (2003) state that "the range of dishonest practice is limited only by students' abilities to use technology creatively" (p. 470). In this case, why not use our students' supposed creativity to our own advantage?

The way instructors plan tasks to counteract cyber-plagiarism should be just one of the aspects within a wider anti-plagiarism strategy, which will be aimed at educating the whole university community. Teachers not only need to be trained to rethink their tasks, they must also be able to convey to students that cyberplagiarism is a dishonest act. The creation of reference manuals and the organization of training seminars for the faculty in which the design of tasks is explained, are actions to be taken by the institutions. Undoubtedly, these measures can help to raise awareness in those members of the faculty who may be allowing students to resort to unintelligent and immature strategies when doing and submitting their work.

Students need to be educated on academic honesty as well, and this is not only the faculty's responsibility. It is the university, sometimes through the student services, the library or the writing and documentation centers, which needs to be in charge. Anyway, it will be important to educate students from the early phases of schooling and make this a continued training throughout higher education, hence instructors' responsibility to advocate the development of integrity in teaching to give credibility to our educational system.

\section{REFERENCES}

Al Darwish, S., \& Sadeqi, A. A. (2016). Reasons for college students to plagiarize in EFL writing: Students' motivation to pass. International Education Studies, 9(9), 99. https://doi.org/10.5539/ies.v9n9p99

Angelo, T. A., \& Cross, K. P. (1993). Classroom assessment techniques: A handbook for college teachers. John Wiley \& Sons.

Barberà, E. (2016). Aportaciones de la tecnología a la E-evaluación. Revista de Educación a Distancia (RED), 50(4). https://doi. org/10.6018/red/50/4

Batane, T. (2010). Turning to Turnitin to Fight Plagiarism among University Students. Educational Technology \& Society, 13(2), 1-12. https://www.ds.unipi.gr/ et\&s/journals/13_2/1.pdf 
Bessy, C., \& Chateauraynaud, F. (2015). Alertes et chuchotements. Questions de communication, (27), 189-204. https:// doi.org/10.4000/ questionsde communication. 9800

Bergadàa, M. (2009). Une situation saugreune. Culture \& Société-Sciencesdel'Homme, 9, 29-33. https://responsable-unige.ch/ assets/files/cultureSocietes2009.pdf

Born, A. D. (2003). Teaching tip. How to reduce plagiarism. Journal of Information Systems Education, 14(3), 223224. http://jise.org/Volume14/n3/ JISEv14n3p223.pdf

Cavanillas, S. (2008). Cyberplagiarism in University Regulations. Digithum, 10. https://www.researchgate. net/publication/26575383 Cyberplagiarism in University Regulations

Cebrián-Robles, V., Raposo-Rivas, M., Cebriánde-la-Serna, M., \& Sarmiento-Campos, J. A. (2018). Percepción sobre el plagio académico de estudiantes universitarios españoles. Educación XXI, 21(2), 159-129. https://doi.org/10.5944/ educxx1.20062

Comas, R., Sureda, J., Casero, A., \& Morey, M. (2011). La integridad académica entre el alumnado universitario español. Estudios pedagógicos (Valdivia), 37(1), 207-225. https://doi.org/10.4067/s $\underline{0718-07052011000100011}$

Chew, E., Ding, S. L., \& Rowell, G. (2013). Changing attitudes in learning and assessment: Cast-off 'plagiarism detection' and cast-on self-service assessment for learning. Innovations in Education and Teaching International, 52(5), 454-463. https://doi.org/10.1080/ $\underline{14703297.2013 .832633}$
Christensen, G. J. (2011). Plagiarism: Can it be stopped? Business Communication Quarterly, 74(2), 201-204. https://doi. org/10.1177/1080569911404403

Davids, N., \& Waghid, Y. (2017, 5 de junio). University tests should be part and parcel of teaching - not stand-alone events. The Conversation. https:// theconversation.com/university-testsshould-be-part-and-parcelof-teachingnot-stand-alone-events-78481

Dawson, J. (2004). Plagiarism: What's really going on? In Seeking Educational Excellence. 13th Annual Teaching Learning Forum. (p.9-10). Perth: Murdoch University.

Devlin, M., \& Gray, K. (2007). In their own words: A qualitative study of the reasons Australian university students plagiarize. Higher Education Research \& Development, 26(2), 181-198. https://doi. org/10.1080/07294360701310805

Dickey, M. (2004). The impact of web-logs (blogs) on student perceptions of isolation and alienation in a web-based distancelearning environment. Open Learning: The Journal of Open, Distance and e-Learning, 19(3), 279-291. https://doi. org/10.1080/0268051042000280138

Dordoy, A. (2002). Cheating and Plagiarism: Staff and Student Perceptions at Northumbria. Northumbria University Conference "Educating for the Future". 
Fernández, M., Godoy Guglielmone, M., Mariño, S., \& Barrios, W. (2017). ¿Invirtiendo la clase o invirtiendo en la clase? Enseñanza de tecnología para la producción multimedia mediante Aula invertida. XXIII Congreso Argentino de Ciencias de la Computación, La Plata, Argentina. http://sedici.unlp. edu.ar/bitstream/handle/10915/63889/ Documento completo.pdf? sequence $=1$

Forte, A., \& Bruckman, A. (2006). From Wikipedia to the classroom: exploring online publication and learning. 7th International Conference on Learning Sciences, Bloomington, Indiana. https:// www.cc.gatech.edu/ asb/papers/ conference/forte-bruckman-icls06.pdf

Fraser, R. (2014). Collaboration, collusion and plagiarism in computer science coursework. Informatics in Education, 13(2), 179-195. https://doi.org/10.15388/ infedu.2014.10

Gómez-Espinosa, M., Francisco, V., \& Moreno-Ger, P. (2016). The impact of activity design in internet plagiarism in higher education. Comunicar, 24(48), 39-48. https://doi.org/10.3916/ c48-2016-04

Hale, M. (2018). Thwarting plagiarism in the humanities classroom: Storyboards, scaffolding, and a death fair. Journal of the Scholarship of Teaching and Learning, 18(4). https://doi.org/10.14434/josotl. $\underline{\mathrm{v} 18 \mathrm{i} 4.23174}$

Harris, R. (2012, February 28). Anti-Plagiarism Strategies for Research Papers. VirtualSalt. https://www.virtualsalt.com/
Hass, M., \& Osborn, J. (2007). An emic view of student writing and the writing process. Across the Disciplines. https:// wac.colostate.edu/atd/articles/hass osborn2007.cfm/

Heckler, N. C., Rice, M., \& Hobson Bryan, C. (2013). Turnitin systems. A Deterrent to Plagiarism in College Classrooms. Journal of Research on Technology in Education, 45(3), 229-248. https://doi.or $\mathrm{g} / 10.1080 / 15391523.2013 .10782604$

Heine, C., \& Martín García, J. M. (2013). Estrategias para prevenir y detectar el plagio académico en Humanidades (PID 11-231). En L. M. Jiménez del Barco Jaldo y M. C. García Garnica (Eds.). Innovación docente y buenas prácticas en la Universidad de Granada (pp. 11681179). Universidad de Granada.

Holley, D., \& Boyle, T. (2012). Empowering teachers to author multimedia learning resources that support students' critical thinking. EURODL. European Journal of Open and Distance Learning. https:// files.eric.ed.gov/fulltext/EJ979598.pdf

Howard, R. M. (2002). Don't police plagiarism: Just teach! The Education Digest 67(5), 46-49. https://search. proquest. com/openview/11c92cd4eba49ea 6703625f694e8788a/1.pdf?pq-origsite= gscholar\&cbl=25066

(2007). Understanding "Internet plagiarism". Computers and Composition, 24(1),3-15. https://doi.org/10.1016/j. compcom. 2006.12.005

Iwamoto, D., Hargis, J., Taitano, E. J., \& Vuong, K. (2017).

Analyzing the efficacy of the testing effect using

Kahoot $^{\mathrm{TM}}$ on student performance.

Turkish Online Journal of Distance 
Education, 18(2), 80-93. https://doi. org/10.17718/tojde.306561

Jiménez Torres, D. (2018, 6 de diciembre). El Plagio en la Universidad. El Español. https://www.elespanol.com/ opinion/tribunas/20180914/plagiouniversidad/337836215 12.html $\underline{06 / 12 / 2018}$

Johnson, D. (2004). Plagiarism-proofing assignments. Phi Delta Kappan, 85(7), 549-552 . https://doi.org/10.1177/ $\underline{003172170408500715}$

Jones, I. (2009). Cyber-plagiarism: Different method-same song. Journal of Legal, Ethical, and Regulatory Issues, 12(1), 89-100. https://www.researchgate. net/publication/286897004_Cyberplagiarism_Different_method-same_song

Ledwith, A., \& Rísquez, A. (2008). Using anti-plagiarism software to promote academic honesty in the context of peer reviewed assignments. Studies in Higher Education, 33(4), 371-384. https://doi. org/10.1080/03075070802211562

Lehman, K. (2010). Stemming the Tide of Plagiarism: One Educator's View. Library Media Connection, 9(12), 4447. http://mclanelibrary.pbworks.com/f/ StemmingTheTideOfPlagiarism.pdf

Lessig, L. (2004). Free Culture: How Big Media Uses Technology and the Law to Lock Down Culture and Control Creativity. New York: The Penguin Press.

Mahabeer, P., \& Pirtheepal, T. (2019). Assessment, plagiarism and its effect on academic integrity: Experiences of academics at a university in South Africa. South African Journal of Science, 115(11/12). https://doi.org/10.17159/ sajs.2019/6323
Moreno Jiménez, P. M. and Carrillo Martín, F. (2019). Guía para prevenir, detectar y responder al plagio académico en la universidad. Universidad del Claustro de Sor Juana. Dirección de Servicios Bibliotecarios. https://www.elclaustro. edu.mx/pdf/convocatorias/Plagio $\% 20$ acad\%C3\%A9mico\%202019-Web.pdf

Moten, J., Fitterer, A., Brazier, E., Leonard, J., \& Brown, A. (2013). Examining Online College Cyber Cheating Methods and Prevention Measures. Electronic Journal of e-Learning, 11(2), 139-146. https:// files.eric.ed.gov/fulltext/EJ1012879.pdf

Nuere, S. (2002). E-learning y educación artística: hacia la enseñanza virtual de las artes visuales. Arte, Individuo y Sociedad, 14, 79-103. https://revistas. ucm.es/index.php/ARIS/article/view/ ARIS0202220079A/5848

Olivia-Dumitrina, N., Casanovas, M., \& Capdevila, Y. (2019). Academic writing and the internet: Cyber-plagiarism amongst University students. Journal of New Approaches in Educational Research, 8(2), 112-125. https://doi. org/10.7821/naer.2019.7.407

Olt, M. R. (2002). Ethics and Distance Education: Strategies for Minimizing Academic Dishonesty in Online Assessment. Online Journal of Distance Learning Administration, 5 (3). https://www. westga.edu/ distance/ojdla/fall53/olt53. pdf

Pardo Iranzo, V. (2014). La docencia online: ventajas, inconvenientes y forma de organizarla. Revista Boliviana de Derecho, 18(38), 622-635. https://www. redalyc.org/pdf/4275/427539914037. pdf 
Park, C. (2003). In Other (People's) Words: Plagiarism by university studentsliterature and lessons. Assessment \& Evaluation in Higher Education, 28(5), 471-488. $\quad$ https://doi. org/10.1080/02602930301677

Pavlakis, A., Kaitelidou, D. (2012). Burnout syndrome in students of a distance learning program: The Open University of Cyprus experience. European Journal of Open, Distance and E-Learning. https:// files.eric.ed.gov/fulltext/EJ979600.pdf

Raes, P. (2009). Se construire un savoir ou plagier: la responsabilité de l'école. Colloque "Copié-coller... », Former à l'utilisation critique et responsable de l'éducation. Bélgique: Pôle universitaire européen de Bruxelles Wallonie et le Centre de l'Economie de la Connaissance de l'Université libre de Bruxelles, 87-104.

Razi, S. (2015). Development of a Rubric to Assess Academic Writing Incorporating Plagiarism Detectors. SAGE Open, 5(2), 1-13. https://doi. org/10.1177/2158244015590162

Reducindo, I., Rivera, L. R., Rivera, J., \& Olvera, M. A. (2017). Integración de plataforma LMS y algoritmo de código abierto para detección y prevención de plagio en Educación Superior. Revista General de Información y Documentación, 27(2), 299-315. https://doi.org/10.5209/ RGID.58205
Ronda-Pérez, E., Seguí-Crespo, M., TausteFrancés, A., Martínez-Martínez, J. M., \& Esteve-Faubel, J. M. (2015). Experiencia piloto de evaluación de una intervención para evitar el plagio académico en alumnos universitarios. En J. D Álvarez Teruel, M. T. Tortosa Ybáñez, y N. Pellín Buades. Investigación y Propuestas Innovadoras de Redes UA para la Mejora Docente, 1932-1947. Alicante: Universidad de Alicante.

Rowe, N. C. (2004). Cheating in Online Student Assessment: Beyond Plagiarism. OnLine Journal of Distance Learning Administration. https://calhoun. nps.edu/bitstream/handle/10945/36015/ Rowe_Cheating_in_Online_Student Assessment.pdf?sequence $=$ 1\&isAllowed $=y$

Ruiz Bejarano, A. M. (2016). Fuentes digitales y fuentes impresas. Prácticas letradas y plagio en el marco universitario. Revista chilena de literatura, 94, 215-230. https://www.redalyc.org/ pdf/3602/360249875011.pdf

Sabieh, C. (2002). An ELT's Solution to Combat Plagiarism: "Birth" of CALL. Annual International Information Technology and Universities in Asia Conference, Bangkok, Tailandia. https://files.eric. ed.gov/fulltext/ED465290.pdf

Salgaonkar, A., \& Manisha, D. (2017). Continuous Engagement and Evaluation of a learner in ODL. ICDE International Conference "Unleashing the Potential of ODL - Reaching the Unreached". Pune, India. http://www.scdl. net/internationalconference/PDFS/ DigitalProceeding/Full\%20paper\%20 of $\% 20$ manisha $\% 20$ divate.pdf 
Sarriá, J. F., \& De Francisco, J. C. (2018). Ciberplagio académico: un tema de importancia. Lite iA tu alcance!, 68, 4-12. https://es.calameo.com/ read/00557874303bfa3c48182

Sentleg, M. P., \& King, L. (2012). Plagiarism among undergraduate students in the Faculty of Applied Science at a South African Higher Education Institution. South African Journal of Library and Information Science - SAJLIS, 78(1), 57-67. https://doi.org/10.7553/78-1-47

Simonnot, B. (2014). Le plagiat universitaire, seulement une question d'éthique? Questions de communication, 26, 219-234. https://doi.org/10.4000/ questionsdecommunication.9304

Stabingis, L., Šarlauskienè, L., \& Čepaitienè, N. (2014). Measures for plagiarism prevention in students' written works: Case study of ASU experience. Procedia - Social and Behavioral Sciences, 110, 689-699. https://doi.org/10.1016/j. sbspro.2013.12.913

Taddei, F. (2009). Former des constructeurs de savoirs collaboratifs et créatifs : Un défi majeur pour l'éducation du 21e siècle. OCDE. https://www.cri-paris. org/en/shared-documents/WEBSITECRI_PDF-oecd-Training-creativecollaborative-fr2009.pdf

Talab, R. (2004). Copyright and you. TechTrends, 48(6), 15-19. https://doi.org/10.1007/ $\underline{\text { bf02763576 }}$
Ohio University. (n.d.). Welcome to Ohio University. https://www.ohio.edul graduate/etd/copyright-plagiarism-andpublishing-information

Thompsett, A., \& Ahluwalia, J. (2010).

Students turned off by Turnitin?

Perception of plagiarism and collusion by undergraduate bioscience students. Bioscience Education, 16(1), 1-15. https://doi.org/10.3108/ beej. 16.3

Tibbetts, Y., Canning, E. A., \& Harackiewicz, J. M. (2015). Academic motivation and performance: Task value interventions. International Encyclopedia of the Social \& Behavioral Sciences, 37-42. https:// doi.org/10.1016/b978-0-08-0970868.26078-9

Underwood, J., \& Szabo, A. (2003). Academic offences and E-IEarning: Individual propensities in cheating. British Journal of Educational Technology, 34(4), 467-477. https://doi.org/10.1111/1467$\underline{8535.00343}$

Biblioguías: Evitar el plagio. Lo Que necesitas saber. Guía para estudiantes universitarios: ¿Como se DETECTA el PLAGIO? (n.d.). Universidad de Extremadura. https://biblioguias. unex.es/plagio academico/ software_antiplagio

Detección y prevención del plagio académico en Humanidades (PID 11-231) (n.d.). Universidad de Granada. https://www. ugr.es/ plagio hum/index.htm 
Guías de la BUS: Evita el plagio en tu trabajo académico: Tipos de plagio. (n.d.). Universidad de Sevilla. https://guiasbus. us.es/plagio_coe/tipos

Université du Québec à Montréal. (n.d.). Tricherie et intégrité académique. https://r18. uqam.cal

Universitat de les Illes Balears. (2020, October 26). Sistemes de detecció de plagi. Servei de Biblioteca i Documentació https://biblioteca. uib.cat/oferta/serveis/ biblioteca investigador/Plagi/Sistemes-dedeteccio-de-plagi.cid511200

University of Maryland. (n.d.). Office of Student Conduct - Promoting Integrity, Character \& Ethics. https://www.studentconduct. umd.edul

University of Oxford (n.d.). Plagiarism. https:// www.ox.ac.uk/students/academic/ guidance/skills/plagiarism?wssl=1 